Journal of Balkumari College

ISSN : 2467-9321 Website: http://www.nepjol.info/index.php/jbkc

Volume : 9, Issue : 1, June 2020, Page No.: 1-12

\title{
The Effect of Firm Specific Variables on Stock Returns of Nepalese Banks
}

\author{
Dr. Jeetendra Dangol ${ }^{1}$ \\ Associate Professor \\ Faculty of Management, \\ Tribhuvan University \\ \& \\ Bidhan Acharya ${ }^{2}$ \\ Freelance Researcher
}

\begin{abstract}
This study focuses to examine the firm specific fundamental variables impact on the stock returns in the context of Nepali banks. The study uses cross sectional panel data of 12 banks for the duration of ten years. The study finds the existence a negative relationship between stock returns (total yield) and firm size. Likewise, the study shows that the book to market equity has negative relationship with stock returns. However, the study reveals that the relationship of earnings yield and cash flow yield with the stock returns is contradicted in comparison to previous studies.
\end{abstract}

Key Words: Firm Size, Stock Returns, Earnings Yield, Cash Flow Yield

\section{INTRODUCTION}

The stock return has always been a significant issue in finance literatures. Markowitz (1952) developed the modern portfolio theory which shows that investors can diversify the investment risk by creating a portfolio of individual securities. Sharpe (1964), Lintner (1965) and Black (1972) further extended Markowitz Portfolio Theory by introducing asset pricing theory, i.e., Capital Assets Pricing Model (CAPM). Other variables also considered by various studies, such as, firm size (Banz, 1981), Book to market equity (BE/ME) ratio (Stattman, 1980), E/P ratio (Basu, 1983) and combined role of beta, size, leverage, $\mathrm{BE} / \mathrm{ME}$ and $\mathrm{E} / \mathrm{P}$ in the cross sections of average stock returns (Fama \& French, 1992).

This study is focused on examining how different firm specific fundamental variables have impact on the stock return in the context of commercial banks of Nepal. Furthermore, the relationship among firm specific variables such as size, book to market equity, earning yield and cash flow yield have also been analyzed.

\section{LITERATURE REVIEW}

Markowitz (1952), "Modern portfolio Theory" suggested that the risk of an individual security is the standard deviation of its returns, a measure of return volatility. Based on the theory of diversification by Markowitz, Sharpe (1964), Linter (1965), and Black (1972) extended the assets pricing theory, which is known as Capital assets pricing model (CAPM).

\section{Size (ME) effect}

Banz (1981) concluded that a negative relationship exists between firm size, measured by market value of equity, and common stock returns. Roll (1981) has provided an explanation for the size effect by stating that smaller firms are riskier and therefore deserve higher expected returns. Keim (1983) documented that there is always negative relation between abnormal returns and size and that relation is more pronounced in January than in any other months. Furthermore, Basu (1983) stated that there is distinction between size effect and earnings yield (E/P) effect.

Corresponding author: 1.jdangol@gmail.com 2.bdhnacharya@gmail.com 


\section{Book to market equity (BE/ME) effect}

Stattman (1980) and Rosenberg et al. (1985) found that a firm's book to market equity (BE/ME) is positively related to average stock returns. Furthermore, DeBont and Thaler (1987) confirmed that book to market equity has positive relation with stock returns. Chan et al. (1991) found that book to market equity variable had a predictive role on stock returns in the Japanese stock market.

Fama and French (1992) reported that book-to-market consistently had the greatest power for explaining stock returns. Fama and French (1993) pointed out that the cross section of average returns on US stocks can be explained by excess market return, a size factor, and a book-to-market factor. Kothari et al. (1995) concluded that there is no significant relation between the BE/ME and stock returns. Similarly, Michailidis et al. (2007) concluded that there is a strong impact of book-to-market on common stock return.

\section{Earnings yield (E/P) effect}

Basu (1977) concluded that the stocks with high earnings to price ratio (or, low $\mathrm{P} / \mathrm{E}$ ratios) earned significantly higher returns than stock with low earnings to price ratio. Similarly Ball (1978) documented that E/P contains information on all factors not explained by the CAPM.

Basu (1983) confirmed that the common stock of high E/P firms earn, on average higher risk-adjusted returns than the common stock of low E/P firms. Chan et al. (1991) stated that there is significant premium for earnings yield in Japanese market if the $\mathrm{E} / \mathrm{P}$ variable is considered in isolation but the effect disappears when book to market ratio is added to the regression.

Fama and French (1992) reported an earnings yield effect, which lost its statistical significance when used together with factors such as book to market ratio or firm size. Davis (1994) indicated that earnings yield has the explanatory power in both two-parameter regressions and in multiple regressions that included combination of various variables such as beta, size and price. Giannetti (2007) showed that earnings price ratio is effective in predicting stock returns.

\section{Cash flow yield (C/P) effect}

Chan et al. (1991) was found that there is evidence of a significant relation between average returns and C/P ratio in the Japanese market. Similarly, Davis (1994) reported that cash flow yield has predictive ability with respect to subsequent realized returns, when the difference in book to market equity is controlled. Similarly, Cakici et al. (2015) reported that cash flow yield demonstrate reliable predictive power to forecast stock returns.

\section{Review of Nepalese Studies}

Pradhan and Balampaki (2004) reported that total yield was positively influenced by earnings yield and size and negatively influenced by book-to-market. Book-to-market was found to be more informative than other variables.

Shrestha (2013) found that the firm size and stock return have positive relation. Book to market was found to have strong explanatory power to explain the stock returns, which impacted the stock returns negatively. It was further concluded that both the earnings yield and cash flow yield have negative relationship with stock return. Sejuwal (2015) concluded that the firm size, book to market and earnings yield have the explanatory power to explain the cross sectional stock returns. Firm size was found to have positive impact and book-to-market was found to have negative relation with stock returns respectively. Thus, this paper has sought to examine the impact of firm specific variables on stock return of banks.

\section{OBJECTIVES}

The study seeks to examine the relationship of dividend yield, capital gain yield and total yield with the firm specific variables such as size, book to market equity, earnings yield and cash flow yield in the context of Nepalese banks. 


\section{DATA AND METHODS}

\section{Data and Selection of Commercial Banks}

The study is based on the secondary data. The study covers ten years data from 2005/06 to 2014/15. All the banks listed in the Nepal Stock Exchange (NEPSE) have been considered as the total population of the study. The sample banks of the study fulfill the following criteria:

- The bank should be listed in the Nepal Stock Exchange.

- The bank should be the one which has not been merged with other financial institution during the study period Using above criteria, twelve banks are selected. They include (1) Bank of Kathmandu, (2) Everest Bank, (3) Himalayan Bank, (4) Kumari Bank, (5) Laxmi Bank, (6) Lumbini Bank, (7) Nabil Bank, (8) Nepal Bangladesh Bank, (9) Nepal Credit and Commerce Bank, (10) Nepal Investment Bank, (11) Nepal SBI Bank, and (12) Standard Chartered Bank.

\section{Methods}

Causal comparative research design has been used in the study. To explain the relationship between firm specific variables, such as, book to market equity, earning yield, cash flow yield, size and capital gain yield, dividend yield, total yield, the following three techniques used to analysis data:

(1) Portfolio formation and analysis: Four portfolios (as per percentiles) have been formed on the basis of size, book to market equity, earnings yield and cash flow yield.

(2) Correlation Analysis: Pearson's correlation coefficient has been used to examine the relationship among each pair of variables.

- Regression Analysis: regression can be framed as under:

$\mathrm{R}=f(\mathrm{LME}, \mathrm{BE} / \mathrm{ME}, \mathrm{E} / \mathrm{P}, \mathrm{C} / \mathrm{P})$

$\mathrm{R}=\mathrm{a}+\mathrm{b}_{1}(\mathrm{LME})+\mathrm{b}_{2}(\mathrm{BE} / \mathrm{ME})+\mathrm{b}_{3}(\mathrm{E} / \mathrm{P})+\mathrm{b}_{4}(\mathrm{C} / \mathrm{P})+\mathrm{U}_{\mathrm{i}}$

Where, dependent variables, $\mathrm{R}$ are:

$\mathrm{DY}=$ Dividend yield, $\mathrm{CY}=$ Capital gain yield, and $\mathrm{TY}=$ Total yield

The independent variables are:

$\mathrm{LME}=$ Size or market capitalization, $\mathrm{BE} / \mathrm{ME}=$ Book to market equity, $\mathrm{E} / \mathrm{P}=$ Earnings yield, $\mathrm{C} / \mathrm{P}=$ Cash flow yield, and $\mathrm{U}_{\mathrm{i}}=$ Disturbance or error term

\section{Definition of variables}

The stock returns of banks are taken as the dependent variable. Dividend yield, capital gain yield and total yield are used as a proxy for stock returns. Firm size, book-to-market equity, earnings yield and cash flow yield are used as the independent variables.

- Dividend Yield (DY): Dividend yield is the ratio of cash dividend per share (DPS) and Market price per share of previous year.

- Capital Gain Yield (CY): Capital gain yield or capital gain per share is obtained by dividing the change in market price of the stock of a firm during the year by market price of previous year.

- Total Yield (TY): Total yield per share is the total yield obtained from a stock including both capital gain yield (CY) and dividend yield (DY). Total yield and stock returns have been used as interchangeable terms in this study.

- Size (LME): Chan et al. (1991) have used the market value of equity (market capitalization) as the representative of firm size. Therefore, size in this study is also represented by the market capitalization of the stock. It can be calculated by multiplying the market price per share to number of shares outstanding. In this study, the natural logarithm of market capitalization (LME) used as a proxy for firm size.

- Book to market equity (BE/ME): Book to market equity ratio is the ratio between book value of equity and 
the market value of equity.

- Earnings yield (E/P): Earnings yield is the earnings available to common stockholders divided by market value of equity.

- Cash flow yield (C/P): Cash flow yield is the free cash flow divided by the market value of equity (market capitalization). Free cash flow is calculated by subtracting capital expenditure and dividend from the cash flow from operating activities.

\section{EMPIRICAL ANALYSIS AND FINDINGS}

\section{Portfolio Formation and Analysis}

Variables are analyzed at portfolio levels by sorting portfolios based on fundamental variables. Four portfolios (as per percentiles) are formed on the basis of size, book to market equity, earnings yield and cash flow yield.

\section{Properties of portfolios sorted by firm size}

Table 1 presents the descriptive statistics (means and standard deviations) associated with four equal percentile groups of portfolios sorted on firm size. The firm size has been measured on the basis of market value of equity.

Table 1

Properties of portfolios sorted by firm size

\begin{tabular}{|c|c|c|c|c|}
\hline & \multicolumn{4}{|c|}{ Portfolio sorted by Firm Size } \\
\hline & 1 & 2 & 3 & 4 \\
\hline Variables & $<5380.25$ & 5380.25 to 11478.02 & 11478.02 to 23637.87 & $>23637.87$ \\
\hline \multirow{2}{*}{ ME (in million) } & 3535.07 & 8564.98 & 14857.54 & 39344.21 \\
\hline & $(1333)$ & $(1724.92)$ & $(2748.50)$ & $(13277.41)$ \\
\hline \multirow{2}{*}{ DY (in percent) } & 0.80 & 1.40 & 1.25 & 1.72 \\
\hline & $(1.72)$ & $(1.72)$ & $(1.31)$ & $(1.40)$ \\
\hline \multirow{2}{*}{ CY (in percent) } & 20.52 & 21.28 & 14.66 & 8.77 \\
\hline & $(75.11)$ & $(52.70)$ & $(55.76)$ & $(42.91)$ \\
\hline \multirow{2}{*}{ TY (in percent) } & 21.32 & 22.68 & 15.91 & 10.50 \\
\hline & $(75.51)$ & $(53.31)$ & $(55.98)$ & $(43.88)$ \\
\hline \multirow{2}{*}{ BME (times) } & 0.26983 & 0.2375 & 0.2131 & 0.1363 \\
\hline & $(0.51289)$ & $(0.1540)$ & $(0.0860)$ & $(0.0556)$ \\
\hline \multirow{2}{*}{$\mathrm{E} / \mathrm{P}$ (in percent) } & -3.51 & 4.88 & 4.42 & 3.50 \\
\hline & $(35.60)$ & $(2.32)$ & $(1.98)$ & $(1.20)$ \\
\hline \multirow{2}{*}{$\mathrm{C} / \mathrm{P}$ (in percent) } & 8.96 & 7.10 & 6.57 & 3.36 \\
\hline & $(27.22)$ & $(10.27)$ & $(11.22)$ & (7.93) \\
\hline $\mathrm{N}$ & 30 & 30 & 30 & 30 \\
\hline
\end{tabular}

Note: Figures in the parentheses are the standard deviations.

Table 1 demonstrates the negative relationship between size and total yield. It shows that larger the size of the commercial banks the lower is the total yield. The average of total yield declined from 21.32 for the smallest portfolio to 10.50 percent for the largest portfolio. This finding is consistent with the finding of Banz (1981), Chan et al. (1991), Fama and French (1992). They found that the large firms earn lower return than the smaller firm. However, the result contradicts to Pradhan (2003), who concluded that total yield is positively related to size. In addition to that, the total yield of banks with smaller firm size is more variable than the total yield of bank with larger firm size. 
Furthermore, there exists negative relation of size with capital gain yield, book-to-market equity, earning yield and cash flow yield. The average capital gain yield decreased from 20.52 percent for lowest portfolio to 8.77 percent for the highest portfolio. The average of book to market equity decreased from 0.2698 times for lowest portfolio to 0.1363 times for the highest portfolio. There is positive relation of firm size with dividend yield.

\section{Properties of portfolios sorted by book-to-market equity}

Table 2 presents the descriptive statistics (means and standard deviations) associated with four equal percentile groups of portfolios sorted on book to market equity.

Table 2

Properties of portfolios sorted by book to market equity

\begin{tabular}{lcccc}
\hline & \multicolumn{4}{c}{ Portfolio sorted by Book to Market Equity } \\
\hline \multirow{2}{*}{ Variables } & 1 & 2 & 3 & 4 \\
\cline { 2 - 5 } & $<0.1199$ & 0.1199 to 0.2008 & 0.2008 to 0.3157 & $>0.3157$ \\
\hline BME (times) & -0.0533 & 0.1571 & 0.2555 & 0.4975 \\
DY (in percent) & $(0.3127)$ & $(0.0256)$ & $(0.0380)$ & $(0.2127)$ \\
& 0.84 & 1.83 & 1.69 & 0.80 \\
CY (in percent) & $(1.13)$ & $(1.73)$ & $(1.60)$ & $(1.51)$ \\
& 40.00 & 19.37 & 10.72 & -4.86 \\
TY (in percent) & $(69.15)$ & $(44.46)$ & $(62.95)$ & $(40.82)$ \\
& 40.84 & 21.20 & 12.41 & -4.06 \\
ME (in million) & $(69.26)$ & $(45.30)$ & $(63.46)$ & $(41.68)$ \\
& 23119.58 & 21913.91 & 14270.61 & 6396.33 \\
E/P (in percent) & $(20371.19)$ & $(15701.18)$ & $(9445.22)$ & $(3621.69)$ \\
& -8.64 & 3.91 & 6.20 & 7.82 \\
C/P (in percent) & $(32.61)$ & $(1.26)$ & $(6.86)$ & $(6.36)$ \\
& 3.82 & 4.06 & 5.65 & 12.46 \\
& $(6.91)$ & $(9.33)$ & $(9.85)$ & $(27.73)$ \\
\hline N & 30 & 30 & 30 & 30
\end{tabular}

Note: Figures in the parentheses are the standard deviations.

Table 2, the total yield showed a declining trend from smallest book-to-market equity group to the largest book-to-market equity. This finding indicates that, the stock having high book-to-market equity have lower total yield. The average total yield decreased from 40.84 percent for the lowest portfolio to negative 4.06 percent for the highest portfolio. The findings of declining trend of total yield with book-to-market ratio in this study is contradicted with findings of earlier studies, such as by Stattman (1980), Rosenberg, Reid and Lanstein (1985), Chan, Hamao and Lakonishok (1991), Fama and French (1992) and Davis (1994), found that stock returns increase with bookto-market equity. However, the result confirms to Prasai (2010) in Nepal. The variation in total yield declined from 69.26 percent for the smallest portfolio to 41.68 percent for the largest portfolio.

Similarly, the stock having high book-to market equity has lower dividend yield and capital gain yield. The average dividend yield decreased from 0.84 percent for the smallest portfolio to 0.80 percent for the largest portfolio. Additionally, the average capital gain yield decreased from 40 percent for the smallest portfolio to negative 4.86 percent for the largest portfolio. Table 2 also indicates that there is negative relationship between book-to-market equity and firm size (market equity). Furthermore, the result documented that stock having higher book-to-market have higher earning yield and cash flow yield. The average earning yield increased from negative 8.64 percent for the smallest portfolio to 7.82 percent for the largest portfolio. Similarly, the average cash flow yield increased from 3.82 percent for the lowest portfolio to 12.46 percent for the highest portfolio. 


\section{Properties of portfolios sorted by earnings yield}

Table 3 presents the descriptive statistics (means and standard deviations) associated with four equal percentile groups of portfolios sorted on earnings yield.

Table 3

Properties of portfolios sorted by earnings yield

\begin{tabular}{lcccc}
\hline & \multicolumn{4}{c}{ Portfolio sorted by Earnings Yield } \\
\hline \multirow{2}{*}{ Variables } & 1 & 2 & 3 & 4 \\
\cline { 2 - 5 } & $<0.0293$ & 0.0293 to 0.0398 & 0.0398 to 0.0612 & $>0.0612$ \\
\hline E/P (in percent) & -9.58 & 3.42 & 4.98 & 10.46 \\
DY (in percent) & $(31.70)$ & $(0.32)$ & $(0.65)$ & $(7.94)$ \\
& 1.00 & 1.04 & 2.07 & 1.06 \\
CY (in percent) & $(1.60)$ & $(0.86)$ & $(1.82)$ & $(1.59)$ \\
& 38.24 & 13.56 & 15.96 & -2.52 \\
TY (in percent) & $(61.54)$ & $(56.75)$ & $(45.70)$ & $(58.10)$ \\
& 39.25 & 14.59 & 18.02 & -1.46 \\
BME (times) & $(61.80)$ & $(57.17)$ & $(46.88)$ & $(58.42)$ \\
& 0.0127 & 0.1885 & 0.2610 & 0.3946 \\
ME (in million) & $(0.3358)$ & $(0.0779)$ & $(0.1344)$ & $(0.2964)$ \\
& 19567.90 & 22164.29 & 16371.03 & 7597.20 \\
C/P (in percent) & $(16855.44)$ & $(18504.24)$ & $(12548.86)$ & $(5614.10)$ \\
& 2.93 & 5.73 & 6.37 & 10.96 \\
& $(7.07)$ & $(7.48)$ & $(15.94)$ & $(25.61)$ \\
\hline
\end{tabular}

Note: Figures in the parentheses are the standard deviations.

Table 3 indicates that the stocks with higher earnings yield have lower total yield. The average total yield decreased from 39.25 percent for the lowest portfolio to negative 1.46 percent for the highest portfolio. However, this finding contradicts to Ball (1978), Jaffe, Keim, and Westerfield (1989), Chan, Hamao and Lakonishok (1991), and Davis (1994), which revealed that high earnings yield stocks outperform low earnings yield stocks. The variation in total yield of portfolio with lower earnings yield is greater than the variation in total yield of portfolio with higher earnings yield.

Table 3 also shows that, the stocks with high earnings yield have lower capital gain yield. The average capital gain yield decreased from 38.24 percent for the lowest portfolio to negative 2.52 percent for the highest portfolio. However, the earning yield have positive relationship with dividend yield. The results indicated that average dividend yield increased from 1 percent for the lowest portfolio to 1.06 percent for the highest portfolio.

Similarly, the result showed that the earning yield have negative relationship with market equity and positive relationship with book to market equity and cash flow yield. The average market equity decreased form Rs. 19,567.90 million for the lowest portfolio to Rs.7,597.20 million for the highest portfolio. Similarly, the average book-to-market equity increased from 0.0127 times for the lowest portfolio to 0.3946 times for the highest portfolio. The average cash flow yield increased from 2.93 percent for the smallest portfolio to 10.96 percent for the largest portfolio.

The variation in portfolio with lower earnings yield is greater than the portfolio with higher earings yield in the context of dividend yield, capital gain yield, total yield, market equity, and book-to-market equity. However, in case of cash flow yield variation is lower in smaller portfolio than larger portfolio. 


\section{Properties of portfolios sorted by cash flow yield}

Table 4 presents the descriptive statistics (means and standard deviations) associated with these portfolios sorted on cash flow yield.

Table 4

Properties of portfolios sorted by cash flow yield

\begin{tabular}{ccccc}
\hline & \multicolumn{4}{c}{ Portfolio sorted by Cash Flow Yield } \\
\hline \multirow{2}{*}{ Variables } & 1 & 2 & 3 & 4 \\
\cline { 2 - 5 } & $<-0.02228$ & -0.0022 to 0.0468 & 0.0998 to 1.0243 & $\geq 1.0243$ \\
\hline C/P(in percent) & -7.93 & 2.53 & 7.51 & 23.87 \\
& $(8.83)$ & $(1.08)$ & $(1.70)$ & $(20.62)$ \\
DY (in percent) & 1.26 & 1.41 & 1.47 & 1.03 \\
& $(1.79)$ & $(1.80)$ & $(1.35)$ & $(1.28)$ \\
CY (in percent) & 7.37 & 38.11 & 12.50 & 7.26 \\
& $(51.27)$ & $(66.64)$ & $(49.59)$ & $(57.20)$ \\
TY (in percent) & 8.63 & 39.52 & 13.97 & 8.28 \\
& $(51.56)$ & $(67.28)$ & $(50.25)$ & $(57.49)$ \\
BME (times) & 0.1322 & 0.1750 & 0.2424 & 0.3072 \\
& $(0.3417)$ & $(0.1314)$ & $(0.1103)$ & $(0.3779)$ \\
E/P (in percent) & -1.49 & 3.76 & 4.61 & 2.41 \\
& $(30.62)$ & $(3.03)$ & $(2.70)$ & $(18.71)$ \\
ME (in million) & 16712.49 & 17399.07 & 19153.86 & 12435.01 \\
& $(15463.73)$ & $(12160.34)$ & $(18984.75)$ & $(13324.94)$ \\
\hline
\end{tabular}

Note: Figures in the parentheses are the standard deviations.

Table 4 shows the negative relationship between total yield and cash flow yield as high cash flow yields have low total yield. The average total yield decreased from 8.63 percent for the smallest portfolio 1 to 8.28 percent for the largest portfolio 4. Similarly, the capital gain yield also decreased for small portfolio from 7.37 percent to 7.26 percent for large portfolio. These findings are consistent with the finding that the stocks having high cash flow yield have lower capital gain yield and total yield (Pradhan, 2004).

However, the dividend yield increased for three portfolio from 1.26 percent for portfolio 1 to 1.47 percent for portfolio 3 and later decreased to 1.03 percent in portfolio 4 . Additionally, the results further showed that there is a positive relation of cash flow yield with book to market equity. The book to market equity increased from 0.13 times for small portfolio to 0.30 times for large portfolio. There is increase in both earnings yield and market equity from portfolio 1 to portfolio 3 but there is decrease in both earnings yield and market equity from Portfolio 3 to Portfolio 4.

Table 4 further indicates that there is greater variation in portfolio with higher cash flow yield than in portfolio with lower cash flow yield in case of book to market equity, capital gain yield and total yield. However, there is greater variation in portfolio with lower cash flow yield than in portfolio with higher cash flow yield in case of dividend yield, earning yield and firm size (market equity).

\section{Correlation Analysis}

Table 5 shows Correlation Coefficients among different pairs of variables used in the study such as Firm size (ME), Book to market equity (BME), earnings yield (EY), Cash flow yield (C/P), Capital gain yield (CY), Dividend yield (DY) and Total yield (TY). 
Table 5

Correlation analysis

\begin{tabular}{cccccccc}
\hline & $\mathrm{ME}$ & $\mathrm{BEME}$ & $\mathrm{E} / \mathrm{P}$ & $\mathrm{C} / \mathrm{P}$ & $\mathrm{CY}$ & $\mathrm{TY}$ & $\mathrm{DY}$ \\
\hline $\mathrm{ME}$ & 1 & & & & & & \\
BEME & -0.166 & 1 & & & & & \\
E/P & 0.09 & $.726^{* *}$ & 1 & & & & \\
C/P & -0.103 & $.293^{* *}$ & 0.063 & 1 & & & \\
CY & -0.092 & $-.257^{* *}$ & -0.029 & -0.062 & 1 & & \\
TY & -0.07 & $-.256^{* *}$ & -0.025 & -0.063 & $1.000^{* *}$ & 1 & \\
DY & 0.129 & 0.037 & 0.117 & -0.063 & $.293^{* *}$ & $.315^{* *}$ & 1 \\
\hline
\end{tabular}

**. Correlation is significant at the 0.01 level (2-tailed).

Table 5 shows that the total yield is significantly positively related with capital gain yield and dividend yield. Similarly, total yield is significantly negatively related with book-to-market equity. The relationship of the total yield with firm size (market equity), earnings yield and cash flow yield is negative but the relation is not statistically significant. Among firm related fundamental variables, the highest correlation coefficient is accounted to be 0.726 which is statistically significant between book to market equity and earnings yield.

There exists significant positive relation of earnings yield and cash flow yield with book to market equity. Likewise there is positive relationship between earnings yield and cash flow yield. This result is consistent to Pradhan and Balampaki (2004). Similarly, there exists positive relation book-to-market equity and dividend yield. There exists significant negative relation between capital gain yield and book-to-market equity.

There exists negative relation between firm size and book to market equity. Firm size is positively related with earning yield and dividend yield and negatively related with other fundamental variables. But the relationship of size with earnings yield is contradictory in portfolio and correlation analysis. Earning yield is positively related with cash flow yield and dividend yield and negatively with capital gain yield and total yield. Dividend yield is positively and significantly related with total yield and capital gain yield.

Low correlations being observed among different pairs of explanatory variables, which are the relationship between total yield and earning yield, earning yield and capital gain yield and dividend yield and book to market equity. Table 5 also reveals that book-to-market equity is more related with earning yield with a positive and statistically significant.

\section{Regression Analysis}

The first four models include one of the four independent variables at a time. Model V to VII include various combinations of the fundamental variables and model VIII includes all the four fundamental variables simultaneously.

\section{Regression between capital gain yield and fundamental variables}

Table 6 presents the regression results. The overall results show the negative relationship of capital gain yield with size and book to market equity, and cash flow yield. In every model, the relationship of size and book to market equity is negative with capital gain yield. Moreover, the coefficients of size and book to market equity are also significant. The relationship of earnings yield and cash flow yield with capital gain yield is contradictory because the relationship is not same in every model.

In model VI and VIII, earnings yield has positive relationship with capital gain yield and these two models are significant. But from portfolio and correlation analysis, it was found that earnings yield has negative relationship with capital gain yield, so the overall relationship of earnings yield with capital gain yield cannot be determined. 


\section{Table 6}

Estimated relationship between capital gain yield and fundamental variables

\begin{tabular}{|c|c|c|c|c|c|c|c|}
\hline Model Specification & Constant & LME & BME & $\mathrm{E} / \mathrm{P}$ & $\mathrm{C} / \mathrm{P}$ & $\mathrm{F}$ & $\mathrm{R}^{2}$ \\
\hline $\mathrm{I}$ & $\begin{array}{c}1.325 \\
(1.037)\end{array}$ & $\begin{array}{c}-0.05 \\
(-0.910)\end{array}$ & & & & 0.829 & 0.007 \\
\hline II & $\begin{array}{c}0.278 \\
(4.312 * *)\end{array}$ & & $\begin{array}{c}-0.538 \\
(-2.890 * *)\end{array}$ & & & $8.35 * *$ & 0.066 \\
\hline III & $\begin{array}{c}0.165 \\
(3.120 * *)\end{array}$ & & & $\begin{array}{c}-0.091 \\
(-0.310)\end{array}$ & & 0.096 & 0.001 \\
\hline IV & 0.178 & $\begin{array}{r}(3.1 \\
(-0\end{array}$ & $\begin{array}{l}37 * *) \\
.678)\end{array}$ & & -0.223 & 0.459 & 0.004 \\
\hline V & $\begin{array}{c}1.313 \\
(0.974)\end{array}$ & $\begin{array}{c}-0.05 \\
(-0.852)\end{array}$ & & $\begin{array}{c}-0.009 \\
(-0.029)\end{array}$ & & 0.411 & 0.007 \\
\hline VI & $\begin{array}{c}4.693 \\
(3.364 * *)\end{array}$ & $\begin{array}{c}-0.184 \\
(-3.108 * *)\end{array}$ & $\begin{array}{c}-1.443 \\
(-5.060 * *)\end{array}$ & $\begin{array}{c}1.807 \\
(3.965 * *)\end{array}$ & & $8.868 * *$ & 0.187 \\
\hline VII & $\begin{array}{c}1.691 \\
(1.339)\end{array}$ & $\begin{array}{c}-0.061 \\
(-1.122)\end{array}$ & $\begin{array}{c}-0.552 \\
(-2.824 * *)\end{array}$ & & $\begin{array}{c}-0.002 \\
(-0.007)\end{array}$ & $3.194 *$ & 0.076 \\
\hline VIII & $\begin{array}{c}4.665 \\
\left(3.336^{* *}\right)\end{array}$ & $\begin{array}{c}-0.183 \\
\left(-3.081^{* *}\right)\end{array}$ & $\begin{array}{c}-1.512 \\
(-5.021 * *)\end{array}$ & $\begin{array}{c}1.869 \\
(4.024 * *)\end{array}$ & $\begin{array}{c}0.235 \\
(0.728)\end{array}$ & $6.756^{* *}$ & 0.19 \\
\hline
\end{tabular}

Note: The values in parenthesis are t-values and $* *$ and $*$ shows the results are significant at 1 percent and 5 percent level of significance.

In model 8, when all the fundamental variables are simultaneously included, all variables are found significant except cash flow yield. Therefore, cash flow yield may not play an important role in predicting capital gain yield.

\section{Regression between dividend yield and fundamental variables}

Table 7 shows that size has positive relation with dividend yield. Similarly, book to market equity and earnings yield have positive relation with dividend yield whereas, the cash flow yield has negative relation with dividend yield.

Table 7

Estimated relationship between dividend yield and fundamental variables

\begin{tabular}{cccccccc}
\hline \multicolumn{7}{c}{ Dependent Variable: Dividend Yield } & \\
\hline Model Specification & Constant & LME & BME & E/P & C/P & F & $\mathrm{R}^{2}$ \\
\hline I & -0.055 & 0.003 & & & & 3.904 & 0.032 \\
& $(-1.599)$ & $\left(1.976^{* *}\right)$ & & & & & \\
II & 0.012 & & 0.002 & & & 0.158 & 0.001 \\
& $\left(6.836^{* *}\right)$ & & $(0.397)$ & & & \\
III & 0.013 & & & 0.01 & & 1.641 & 0.014 \\
& $\left(8.823^{* *}\right)$ & & & $(1.281)$ & & & \\
IV & 0.013 & & & -0.006 & 0.471 & 0.004 \\
& $\left(8.611^{* *}\right)$ & & & $(-0.686)$ & & \\
V & -0.047 & 0.003 & & 0.006 & & 2.197 & 0.036
\end{tabular}




$\begin{array}{cccccccc}\text { VI } & -0.046 & 0.003 & 0 & 0.006 & & 1.453 & 0.036 \\ & (-1.119) & (1.453) & (-0.039) & (0.467) & & & \\ \text { VII } & -0.054 & 0.003 & 0.004 & & -0.005 & 1.489 & 0.037 \\ & (-1.532) & (1.895) & (0.675) & & (-0.569) & & \\ \text { VIII } & -0.046 & 0.003 & 0.001 & 0.005 & -0.005 & 1.142 & 0.195 \\ & (-1.101) & (1.434) & (0.119) & (0.368) & (-0.490) & & \\ & & \end{array}$

Note: The values in parenthesis are t-values and $* *$ and $*$ shows the results are significant at 1 percent and 5 percent level of significance.

In model VI, book to market equity is introduced as third independent variable however, it does not affect the predicting power of earning yield and size. In model VIII, when all the fundamental variables are simultaneously included, the variables finds insignificant. The models estimated are insignificant.

\section{Regression between total yield and fundamental variables}

Table 8, first four models, individually the market capitalization (LME) exhibit negative relation with total yield with average slope of negative 0.041 without statistically significant. Earnings yield and cash flow yield individually demonstrate negative relation with total yield.

Table 8

Estimated relationship between total yield and fundamental variables

\begin{tabular}{|c|c|c|c|c|c|c|c|}
\hline \multirow{2}{*}{ Model Specification } & \multicolumn{7}{|c|}{ Dependent Variable: Total Yield } \\
\hline & Constant & LME & BME & $\mathrm{E} / \mathrm{P}$ & $\mathrm{C} / \mathrm{P}$ & $\mathrm{F}$ & $\mathrm{R}^{2}$ \\
\hline \multirow[t]{2}{*}{ I } & 1.135 & -0.041 & & & & 0.531 & 0.005 \\
\hline & $(0.865)$ & $(-0.729)$ & & & & & \\
\hline \multirow[t]{2}{*}{ II } & 0.296 & & -0.54 & & & $8.233 * *$ & 0.066 \\
\hline & $(4.513 * *)$ & & $(-2.869 * *)$ & & & & \\
\hline \multirow[t]{2}{*}{ III } & 0.181 & & & -0.08 & & 0.073 & 0.001 \\
\hline & $\left(3.376^{* *}\right)$ & & & $(-0.27)$ & & & \\
\hline \multirow[t]{2}{*}{ IV } & 0.194 & & & & -0.228 & 0.47 & 0.004 \\
\hline & $(3.386 * *)$ & & & & $(-0.685)$ & & \\
\hline \multirow[t]{2}{*}{$\mathrm{V}$} & 1.117 & -0.041 & & -0.013 & & 0.264 & 0.005 \\
\hline & $(0.805)$ & $(0.675)$ & & $(-0.043)$ & & & \\
\hline \multirow[t]{2}{*}{ VI } & 4.541 & -0.177 & -1.438 & 1.8 & & $8.429 * *$ & \\
\hline & $(3.154 * *)$ & $(-2.891 * *)$ & $(-4.965 * *)$ & $(3.884 * *)$ & & & \\
\hline \multirow[t]{2}{*}{ VII } & 1.489 & -0.052 & -0.552 & & 0.001 & $3.007 *$ & 0.073 \\
\hline & (1.147) & $(-0.921)$ & $(-2.787 * *)$ & & (0.997) & & \\
\hline \multirow[t]{2}{*}{ VIII } & 4.507 & -0.176 & -1.507 & 1.861 & 0.234 & $6.423 * *$ & 0.184 \\
\hline & $(3.122 * *)$ & $(-2.861 * *)$ & $(-4.927 * *)$ & $\left(3.941^{* *}\right)$ & $(0.714)$ & & \\
\hline
\end{tabular}

Note: The values in parenthesis are t-values and ${ }^{* *}$ and $*$ shows the results are significant at 1 percent and 5 percent level of significance respectively..

Similarly, book-to-market equity individually and reliably demonstrates significant negative relation with total yield at 1 percent level of significance respectively. Table 8 shows that among all the four variables book to market value has higher explanatory power than other variables as indicated by significant negative relationship between total yield and book to market value in the model II, VI, VII and VIII. This result contradicts to Chan et al. (1991), Fama and French (1992) but the result is consistent to Pradhan and Balampaki (2004), and Shrestha (2013). 
Likewise, model $\mathrm{V}$, total yield is negatively related with firm size and earnings yield. However, when book to market equity is added in model VI, it is found that total yield is significantly and positively related with earning yield and significantly negatively related with firm size and book to market equity. Model VII shows the similar result when cash flow yield is added and also shows positive relation of total yield with cash flow yield. The results are not consistent with Pradhan (2004). Similarly, model VIII attempts to reveal the joint effect of all variable on total yield.

In every model, size has negative relationship with stock return indicating that the size and the total yield move in the opposite direction in Nepal. This finding is supported by Chan et al. (1991), Fama and French (1992). Size (LME) helps to explain average stock returns and found negative relation with stock return but this result contradicts with the studies conducted in Nepal by Pradhan and Balampaki (2004) and Shrestha (2013).

Among the firm specific variables, the book to market has higher explanatory power than other variables and cash flow yield has lowest explanatory power in comparison to other variables.

\section{CONCLUSION}

The paper examines the effect of firm specific variable on stock returns. The result reveals that there is negative relationship between stock return (total yield) and firm size. The result also showed that book to market equity has negative relationship with stock return. Earnings yield and cash flow yield shows varying relationship with total yield with the change model.

The results indicated that among all the firm specific variables, book to market equity is the most important determinants of stock returns in the Nepalese stock market. Similarly, there is positive relationship among earnings yield, book to market equity ratio and cash flow yield. On the contrary, the size was found to have negative relationship with book to market equity and cash flow yield.

\section{REFERENCES}

Ball, R. (1978). Anomalies in relationships between securities' yields and yield-surrogates. Journal of Financial Economics, 6(2), 103-126.

Banz, R. W. (1981). The relationship between returns and market value of common stocks. Journal of Financial Economics, 9(1), 3-18.

Basu, S. (1977). Investment performance of common stocks in relation to their price earnings ratios: A test of efficient market hypothesis. The Journal of Finance, 32(3), 129-156.

Basu, S. (1983). The relationship between earnings yield, market value, and return for NYSE common stocks: Further evidence. Journal of Financial Economics, 12(1), 129-156.

Black, F. (1972). Capital market equilibrium with restricted borrowing. Journal of Business, 45(3), 444-454.

Cakici, N., Chan, K., \& Topyan, K. (2015). Cross-sectional stock return predictability in China. The European Journal of Finance, 1-25.

Chan, L. K. C., Hamao, Y., \& Lakonishok, J. (1991). Fundamentals and stock returns in Japan. The Journal of Finance, 46(5), 1739-1764.

Daniel, T., Titman, S. (1997). Evidence on the characteristics of cross sectional variation in stock returns. The Journal of Finance, 52, 1-33.

Davis, J. L. (1994). The cross-section of realized stock returns: The Pre-COMPUSTAT evidence. The Journal of Finance, 49(5), 1579-1593.

Fama, E. F. \& French, K. R. (1992). The cross-section of expected stock returns. The Journal of Finance, 47(2), 427-465.

Fama, E. F. \& French, K. R. (1993). Common risk factors in the returns on stocks and bonds. Journal of Financial Economics, 33(1), 3-56.

Giannetti, A. (2007). The short term predictive ability of earnings-price ratios: The recent evidence (1994-2003). The Quarterly Review of Economics and Finance, 47(1), 26-39.

Jaffe, J., Keim, D. B., \& Westerfield, R. (1989). Earnings yield, market values, and stock returns. The Journal of Finance, 44(1), 135-148. 
Keim, D. B. (1983). Size related anomalies and stock return seasonality: Further empirical evidence. Journal of Financial Economics, 12(1), 13-22.

Kothari, S., Shanken, J., \& Sloan, R. (1995). Another look at the cross-section of expected stock returns. The Journal of Finance, 50(1), 185-224

Lintner, J. (1965). The valuation of risk assets and the selection of risky investments in stock portfolios and capital budget. Review of Economics and Statistics, 47, 13-37

Markowitz, H. (1952). Portfolio selection. The Journal of Finance, 7(1), 77-91

Michailidis, G., Tsopoglou, S., \& Papanastasiou, D. (2007). The cross-section of expected stock returns for the Athens stock exchange. International Research Journal of Finance and Economics, 8, 63-96.

Pradhan, R. S. (2003). Effects of dividends on common stock prices: The Nepalese evidence. Research in Nepalese Finance, 2, 90-105.

Pradhan, R. S., \& Balampaki, S. B. (2004). Fundamentals of stock returns in Nepal. SEBO Journal, 1, 8-24.

Prasai, B. K. (2010). CAPM anomalies and pricing of equity: A case of Nepal. (An Unpublished Mphil's Degree Dissertation, FOM, TU, Kirtipur).

Rosenberg, B., Reid, K., \& Lanstein, R. (1985). Persuasive evidence of market inefficiency. Journal of Portfolio Management, 11, 9-17.

Roll, R. (1981). A possible explanation of the small firm effect. The Journal of Finance, 36 (4), 879-888.

Sejuwal, N. (2015). The effect of firm specific variables on stock return: A case of Nepal. (An Unpublished Mphil's Degree Dissertation, FOM, TU, Kirtipur).

Sharpe, W. F. (1964). Capital asset pricing: A theory of market equilibrium under conditions of risk. Journal of Finance, 19, 425-441.

Shrestha, N. R. (2013). Firm specific variables and stock returns in Nepal. (An Unpublished Mphil's Degree Dissertation, FOM, TU, Kirtipur).

Stattman, D. (1980). Book values and stock returns. The Chicago MBA: A Journal of Selected Papers, 4, 25-45. 